\title{
EFFECTS OF WEED MANAGEMENT AND PLANT ARRANGEMENTS ON YIELD INDEX OF SWEET SORGHUM
}

\author{
EFEITO DO MANEJO DE PLANTAS DANINHAS E ARRANJO DE PLANTAS NOS \\ ÍNDICES DE PRODUTIVIDADE DO SORGO SACARINO
}

\author{
Ronaldo Matias REIS'; Matheus Souza FREITAS²; Daniel Valadão SILVA,"; \\ Gustavo Antônio Mendes PEREIRA ${ }^{1}$; Ana Beatriz Rocha de Jesus PASSOS ${ }^{2}$; \\ Alexandre Ferreira da SILVA ${ }^{3}$; Antonio Alberto da SILVA ${ }^{1}$; Marcelo Rodrigues dos REIS ${ }^{4}$ \\ 1. Universidade Federal de Viçosa, Campus Viçosa, Departamento de Fitotecnia, Viçosa, MG, Brasil. ronaldo.reis@ufv.br; \\ 2. Universidade Federal Rural do Semi-Árido, Mossoró, RN, Brasil. danielvaladaos@ yahoo.com.br*; 3. Embrapa Milho e Sorgo, Sete \\ Lagoas, MG, Brasil; 4. Universidade Federal de Viçosa, Rio Paranaíba Campus, Departamento de Fitotecnia, Rio Paranaíba, MG, \\ Brasil.
}

\begin{abstract}
Sweet sorghum is currently an important alternative for ethanol production in sugar cane off-season. In this study was to evaluate the effects of plant arrangements and the application of atrazine and Smetolachlor on growth and productivity of sweet sorghum. An experiment was conducted in randomized block design and, arranged in split plots with four repetitions. Plots consisted of spacing $(0.25 \mathrm{~m}, 0.45 \mathrm{~m}$ 0.45-0.45$0.90 \mathrm{~m})$ and sub-plots of weed control methods - atrazine $\left(2000 \mathrm{~g} \mathrm{ha}^{-1}\right)$, atrazine $+\mathrm{S}$-metolachlor $(2000+720 \mathrm{~g}$ $\left.\mathrm{ha}^{-1}\right)$, atrazine $+\mathrm{S}$-metolachlor $\left(2000+960 \mathrm{~g} \mathrm{ha}^{-1}\right)$, atrazine + S-metolachlor $\left(2000+1200 \mathrm{~g} \mathrm{ha}^{-1}\right)$, atrazine $+\mathrm{S}-$ metolachlor $\left(2000+1440 \mathrm{~g} \mathrm{ha}^{-1}\right)$. Besides that, manual hoeing control was added. The intoxication of sorghum plants and weed control was evaluated at 7, 14 e 28 days after herbicides application (DAA). Plant height, stem diameter, total fresh matter, juice mass and total soluble solids ( ${ }^{\circ}$ Brix) were evaluated at 120 days after crop emergence (DAE). There was no interaction between the factors spacings and control method for variables total matter fresh (TMF), height (H), stem diameter (D), juice mass (JM), and Brix. Application of the mixture (atrazine + S-metolachlor) in the highest doses reduced total fresh matter and ${ }^{\circ}$ Brix. The spacing of $0.25 \mathrm{~m}$ provided the highest productivity of fresh matter, juice mass and increased the ${ }^{\circ}$ Brix. The application of mixture (atrazine $+\mathrm{S}$-metolachlor) controlled $90 \%$ of the weeds at 28 days after application. The increasing in doses of S-metolachlor elevates the intoxication in sorghum plants. The mixture (atrazine + S-metolachlor) has a potential for use in weed control in sweet sorghum, but at doses below $960 \mathrm{~g} \mathrm{ha}^{-1}$ of S-metolachlor.
\end{abstract}

KEYWORDS: Sorghum bicolor. S-metolachlor. Atrazine. Biofuel.

\section{INTRODUCTION}

Sweet sorghum (Sorghum bicolor (L.) Moench.) is an alternative in ethanol production, especially in areas during sugarcane off-season (MAY et al., 2016). Short cycle (90 to 120 days), ease of mechanization and high levels of fermentable sugars present in the stems are advantages of the sweet sorghum compare to others plants (RATNAVATHI et al., 2010).

The initial slow development of sorghum aggravates its susceptibility to weed interference on the first 30 days after emergence (SILVA et al., 2014). The lack of herbicides selective to sorghum has hampered the weeds control, mainly the grasses species. In Brazil, only atrazine is available to the application at pre and post-emergence in sorghum crops. However, this herbicide controls a small number of grasses species (MISHRA et al., 2015).

The association of atrazine with other herbicide molecules, such as mesotrione (WALSH et al., 2012) tembotrione (THEODORO et al., 2018;
BOLLMAN et al., 2009) and nicosulfuron (PEREIRA et al., 2019; SILVA et al., 2019; WILLIAMS et al., 2010) has been used to increase the range weed control in maize. The herbicide Smetolachlor, when applied after maize emergence can control grasses that are in the initial germination process (ARCHANGELO et al., 2002). However, it is necessary to evaluate the effects of S-metolachlor application on the yield and in fermentable sugars accumulation of sweet sorghum plants.

The narrow spacing between rows can reduce weed community interference (SILVA et al., 2014; BRAZ et al., 2019). However, changes in the distance between rows can increase the competition intraspecific and affect the growth and development of sorghum. Studies have shown that the reducing of the spacing increased the fresh matter production of sweet sorghum (ALMODARES et al., 2013). However, others studies found a linear relationship between the solid soluble content (Brix) of the juice and row spacing for sweet sorghum: Increasing $1 \mathrm{~cm}$ 
in spacing, the Brix of the juice was elevated in 0.011 (ALBUQUERQUE et al., 2012).

The objective of this study was to evaluate the effects of the plant spacing and post-emergence application of atrazine + S-metolachlor on the growth and yield of sweet sorghum.

\section{MATERIAL AND METHODS}

The experiment was conducted from November 2013 to March 2014 in the experimental field Prof. Diogo Alves de Melo, in Viçosa (MG) (2046'05" latitude and 45 52'09" longitude, at 650 $\mathrm{m}$ of altitude). The climate of the region is humid subtropical, according to the Köoppen-Geiger classification (Climate-Data, 2019). The average annual temperature was $21^{\circ} \mathrm{C}$ and average annual rainfall of 1,200 $\mathrm{mm}$ (Figure 1).

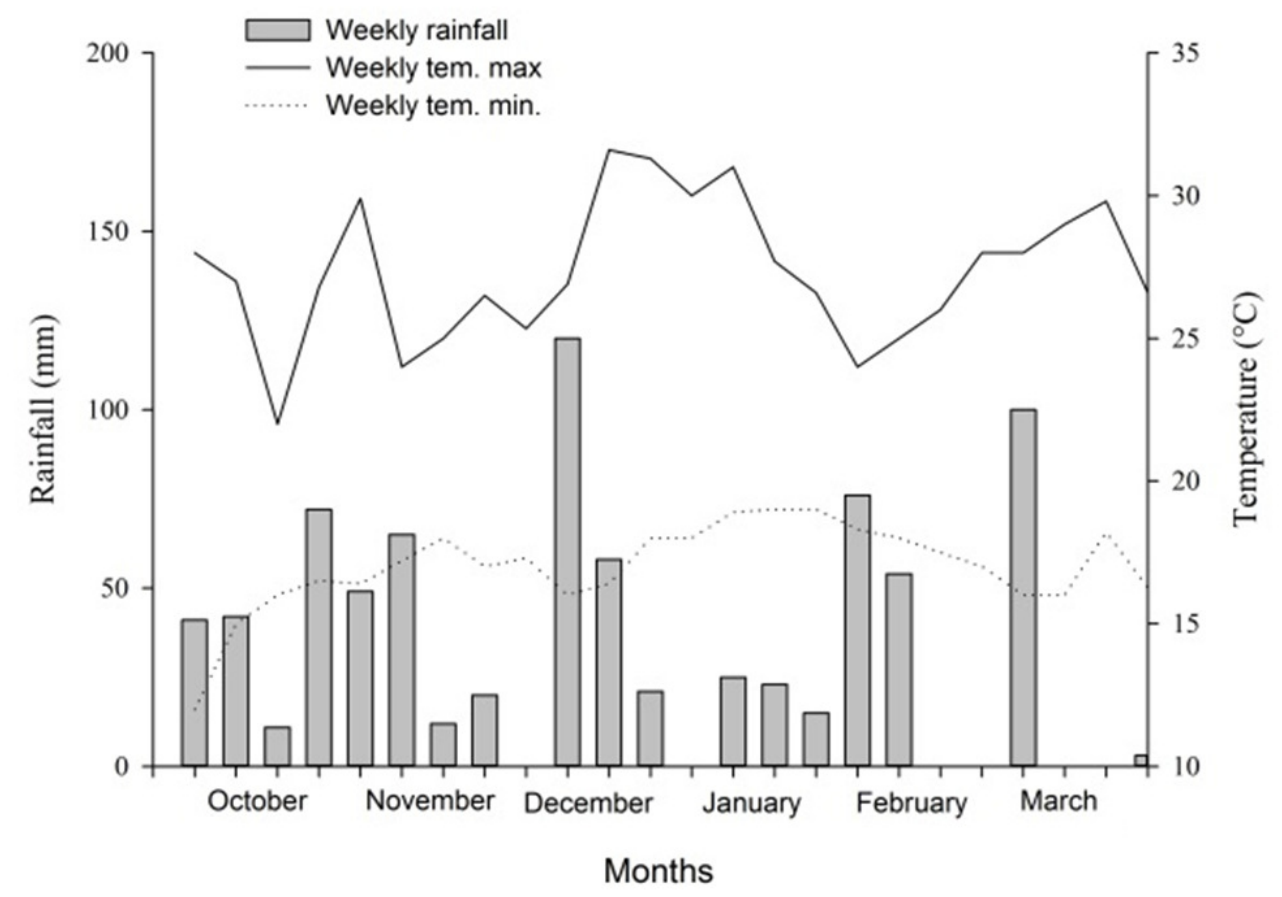

Figure 1. Rainfall and maximum and minimum air temperature during November 1 to March 31, 2014. Viçosa, MG.

Soil was classified as Ultisols (EMBRAPA, 2012) (Table 1). Sorghum plants were fertilized with $300 \mathrm{~kg} \mathrm{ha}^{-1}$ of the formulation 8-28-16 (N-P-K) applied directly on the planting rows. Top dressing fertilization was $300 \mathrm{~kg} \mathrm{ha}^{-1}$ of urea applied at 20 days after emergence.

Experimental design was a randomized completely block design with four replicates. Treatments were arranged in a split-plot design. Plots consisted of spacing $0.25,0.45$, and 0.45-0.45$0.90 \mathrm{~m}$, according described by MAY et al. (2012). Sub-plots was the weed control methods: atrazine $\left(2000 \mathrm{~g} \mathrm{ha}^{-1}\right)$, atrazine + S-metolachlor $(2000+720$ $\left.\mathrm{g} \mathrm{ha}^{-1}\right)$, atrazine + S-metolachlor $\left(2000+960 \mathrm{~g} \mathrm{ha}^{-}\right.$ $\left.{ }^{1}\right)$, atrazine + S-metolachlor $\left(2000+1200 \mathrm{~g} \mathrm{ha}^{-1}\right)$, atrazine + S-metolachlor $\left(2000+1440 \mathrm{~g} \mathrm{ha}^{-1}\right)$. Besides, manual hoeing control was added.

Sweet sorghum cultivar BRS 506 was sown at 140,000 seeds $\mathrm{ha}^{-1}$, and after emergence the population obtained was 120,000 plants $\mathrm{ha}^{-1}$ for all row spacings stipulated. The useful area all of the plots was $4.5 \mathrm{~m}^{2}(1.5 \times 3 \mathrm{~m})$. The production per hectare of fresh matter and juice mass were estimated to considering the average obtained from useful areas $\left(4.5 \mathrm{~m}^{-2}\right)$.

Herbicide application was carried out 11 days after sorghum emergence (DAE), between the stages V1 and V2 of sweet sorghum development (SMITH; FREDERIKSEN 2000), with a $\mathrm{CO}_{2-}$ pressurized backpack sprayer at constant pressure of $2.5 \mathrm{kgf} \mathrm{cm}^{-2}$, TT 110.02 spray nozzles, spaced at 50 $\mathrm{cm}$, at a height of $50 \mathrm{~cm}$ from soil and spray volume of $120 \mathrm{~L} \mathrm{ha}^{-1}$. The application was performed from 07:00 to 09:00 hours, at a temperature of $21.8{ }^{\circ} \mathrm{C}$, relative humidity of $80 \%$ and average wind speed of $6 \mathrm{~km} \mathrm{~h}^{-1}$.

Sorghum plants were irrigated whenever necessary, maintaining the humidity of soil at field capacity. Insecticide deltametrine at the dose of $5 \mathrm{~g}$ $\mathrm{ha}^{-1}$ was applied to control Spodoptera frugiperda. The application of the insecticide was performed 40 
days after emergence, when $20 \%$ of the plants had visual symptoms of attack by the pest.

Weed species observed in experimental area before herbicide application were: Cyperus esculentus, Oxalis latifolia, Avena strigosa, Digitaria horizontalis, Eleusine indica, Urochloa plantaginea, Raphanus raphanistrum, Commelina benghalensis, Eragrotis pilosa, Setaria geniculata, Siegesbeckia orientalis, Stemodia trifoliata, Nicandra physaloides, Emilia sonchifolia and Coronopus didymus. Weed control was evaluated at 7, 14 and 28 days after herbicide application (DAA). Scale control grading based on values from 0 to $100 \%$, which 0 corresponded to absence of weed control and $100 \%$ to total control (SBCPD, 1995). Besides that, on the same dates, visual intoxication of the sorghum plants was measured by using a similar scale.

Sweet sorghum plants were harvested at 120 days after emergence (DAE). The plants harvested were weighed on a digital scale for determination of total fresh matter. Ten plants in each plot were sampled for assessments of plant height (distance from the soil surface to the apex of the panicle) and stem diameter $(60 \mathrm{~cm}$ from the soil). Moreover, the leaves and panicles of the sampled plants were removed, and the stems were crushed with a shredder.

A sample of $0.5 \mathrm{~kg}$ of shredded stem was used in juice extraction, with a hydraulic press at constant pressure of $250 \mathrm{kgf} \mathrm{cm}{ }^{-2}$, for one minute. Juice mass was determined, and an aliquot of $80 \mu \mathrm{L}$ was collected for determination of total soluble solids in a refractometer.

The data were submitted to analysis of variance by the F-test at 5\% probability. When significant, the means of the treatments were compared by Tukey's test at $5 \%$ probability. The effect of increasing rates of the atrazine $+\mathrm{S}$ metolachlor mixture on the variables of weed control and sweet sorghum intoxication was submitted to regression analysis.

\section{RESULTS AND DISCUSSION}

There was no interaction between the factors spacings and control method for variables total matter fresh (TMF), height $(\mathrm{H})$, stem diameter (D), juice mass (JM), and Brix. Therefore, the deployment of interaction was not performed for any variable. The competition with weeds reduced the total fresh matter, height and juice mass production (Table 1). The solid soluble content of sorghum in the plot without weeding was similar to treatments where weeded control was carried out.
The content of soluble solids in the sorghum plants affects the synthesis of ethanol, and those with high ${ }^{\circ}$ Brix can generate greater production of ethanol (HAN et al., 2012). However, the lower mass juice per hectare in plots without weed control will result in lower ethanol production per hectare. Thus, it is necessary to control weeds in sorghum crops to obtain maximum efficiency in ethanol production. The application of atrazine $+\mathrm{S}$-metolachlor reduced ${ }^{\circ}$ Brix; however, the total fresh matter was reduced by $14 \%$ at doses up to 1200 a.i. ha ${ }^{-1}$ of Smetolachlor (Table 1).

Plants have various mechanisms to protect against biotic and abiotic stresses (KATEROVA et al., 2010). Presence of S-metolachlor causes oxidative damage in cells by membrane lipid peroxidation in sorghum plants (GRONWALRD et al., 1987), as well as rice (Oryza sativa) and rapeseed (Brassica napus) plants (LIU et al., 2012; VERCAMPT et al., 2016). In response to this stress, sorghum plants increase the activity of glutathioneS-transferase (GST), changing the state of glutathione (GSH) to redox for detoxication their cells through forming conjugated GSH-Smetolachlor (GRONWALD et al., 1987; VERCAMPT et al., 2016). However, this mechanism is governed by the energy consumption, obtained through breaks in ATP molecules (VERCAMPT et al., 2016), and soluble solids stored in the tissues of sorghum plants may have been used as energy source to ATP production, reducing ${ }^{\circ} \mathrm{Brix}$ in plants where the S-metolachlor was applied.

The lower spacing of sorghum plants increased total fresh matter (Table 2), without affecting others factors, such as juice mass, total soluble solid content, plant height, and stem diameter. The adjustment of plant spacing can elevate the yield of a crop per area. However, planting in high densities intensifies the intraspecific competition, and it reduces yield crop due to the limitation of the growth resources, such as water and nutrients (MAY et al., 2016).

Sorghum BRS 506 cultivated at spacings 0.25 plants $\mathrm{m}^{2}$ showed high yield without affecting others productivity parameters; therefore, this spacing can be recommended to farmers. Others studies evaluate the spacing effect on yield sweet sorghum BRS 506 in different seeding, and both season and off-season crop the spacing rows $0.5 \mathrm{~m}$ between plants resulted in the highest total fresh matter (FERNANDES et al., 2014).

The intercalated spacing $0.45-0.45-0.90$ promoted reduction of total fresh matter (MFT) and juice mass (JM) compared to the other spacings 
(Table 2). The use of this intercalated spacing is to allow mechanized harvesting of sorghum using conventional sugarcane harvesting machines (MAY et al., 2013). However, productivity was affected by the intercalated spacing. This fact may be a result of lower efficiency in the use of solar radiation, water, and nutrients. Narrower spacings can provide better control of weeds due to faster canopy closure, reduce erosion, the cover of the soil surface, and improve planting quality through the slower rotational speed of seed distribution systems (MAY et al., 2016). Therefore, the wider spacing is not a good alternative since the productive indexes of fresh matter and juice weight are reduced.

Table 1. Total fresh matter (TFM), plant height (H) and stem diameter (D), juice mass (JM) and total soluble solid content $\left({ }^{\circ}\right.$ Brix) of sweet sorghum submitted to the weeds control methods.

\begin{tabular}{llllll}
\hline Control method & $\begin{array}{l}\text { TFM } \\
\left(\mathrm{Mg} \mathrm{ha}^{-1}\right)\end{array}$ & $\begin{array}{l}\mathrm{H} \\
(\mathrm{m})\end{array}$ & $\begin{array}{l}\mathrm{D} \\
(\mathrm{mm})\end{array}$ & $\begin{array}{l}\mathrm{JM} \\
\left(\mathrm{Mg} \mathrm{ha}^{-1}\right)\end{array}$ & $\begin{array}{l}{ }^{\circ} \mathrm{Brix} \\
(\%)\end{array}$ \\
\hline Weeded control & $100.25 \mathrm{a}$ & $3,43 \mathrm{a}$ & $20,89 \mathrm{a}$ & $67,45 \mathrm{a}$ & $12.40 \mathrm{a}$ \\
Control without weeding & $81.10 \mathrm{c}$ & $3.18 \mathrm{~b}$ & $20.80 \mathrm{a}$ & $54.35 \mathrm{~b}$ & $13.04 \mathrm{a}$ \\
Atrazine & $100.57 \mathrm{a}$ & $3.47 \mathrm{a}$ & $21.09 \mathrm{a}$ & $69.24 \mathrm{a}$ & $11.73 \mathrm{a}$ \\
${ }^{1}$ Atrazine + S-metolachlor & $88.82 \mathrm{ab}$ & $3.44 \mathrm{a}$ & $21.20 \mathrm{a}$ & $61.34 \mathrm{a}$ & $10.30 \mathrm{ab}$ \\
${ }^{2}$ Atrazine + S-metolachlor & $92.12 \mathrm{ab}$ & $3.44 \mathrm{a}$ & $21.45 \mathrm{a}$ & $64.34 \mathrm{a}$ & $9.92 \mathrm{bc}$ \\
${ }^{3}$ Atrazine + S-metolachlor & $86.79 \mathrm{~b}$ & $3.38 \mathrm{a}$ & $20.41 \mathrm{a}$ & $60.42 \mathrm{a}$ & $10.11 \mathrm{ab}$ \\
${ }^{4}$ Atrazine + S-metolachlor & $87.68 \mathrm{~b}$ & $3.38 \mathrm{a}$ & $21.17 \mathrm{a}$ & $60.66 \mathrm{a}$ & $10.75 \mathrm{ab}$ \\
DMS & 4.02 & 0.09 & 1.53 & 2.65 & 1.12 \\
\hline
\end{tabular}

Means followed by * differ from the control treatment weeded by Tukey test at $5 \%$ probability. ${ }^{1} 2000+720 \mathrm{~g}$ a.i ha ${ }^{-1} ;{ }^{2} 2000+960 \mathrm{~g}$ a.i $\mathrm{ha}^{-1} ;{ }^{3} 2000+1200 \mathrm{~g}$ a.i ha ${ }^{-1} ;{ }^{4} 2000+1440 \mathrm{~g}$ a.i ha ${ }^{-1}$ LSD= least significant difference.

Table 2. Total fresh matter (TFM), plant height (H), stem diameter (D), juice mass (JM) and total soluble solid content ( ${ }^{\circ}$ Brix) of sweet sorghum at different row spacing.

\begin{tabular}{llllll}
\hline Spacing $(\mathrm{m})$ & $\begin{array}{l}\text { TFM } \\
\left(\mathrm{Mg} \mathrm{ha}^{-1}\right)\end{array}$ & $\begin{array}{l}\mathrm{H} \\
(\mathrm{m})\end{array}$ & $\begin{array}{l}\mathrm{D} \\
(\mathrm{mm})\end{array}$ & $\begin{array}{l}\text { JM } \\
\left(\mathrm{Mg} \mathrm{ha}^{-1}\right)\end{array}$ & $\begin{array}{l}{ }^{\circ} \text { Brix } \\
(\%)\end{array}$ \\
0.25 & $104.38 \mathrm{a}$ & $3.45 \mathrm{a}$ & $20.77 \mathrm{a}$ & $70.93 \mathrm{a}$ & $11.8 \mathrm{a}$ \\
0.45 & $90.21 \mathrm{~b}$ & $3.31 \mathrm{a}$ & $20.79 \mathrm{a}$ & $62.88 \mathrm{ab}$ & $10.2 \mathrm{a}$ \\
$0.45-0.45-0.90$ & $78.54 \mathrm{~b}$ & $3.39 \mathrm{a}$ & $21.44 \mathrm{a}$ & $53.92 \mathrm{~b}$ & $11.2 \mathrm{a}$ \\
LSD & 3.82 & 0.09 & 1.53 & 9.65 & 0.82 \\
\hline
\end{tabular}

Means followed by the same letter in the column do not differ by Tukey test at $5 \%$ probability. $\mathrm{LSD}=$ least significant difference.

The application of atrazine + S-metolachlor intoxicated sweet sorghum plants even at lower doses, and a linear increase of intoxication occurred due to the increasing doses of S-metolachlor at 7, 14, and 28 DAA (Figure 2). The high initial intoxication of sorghum plants, at doses up to $960 \mathrm{~g}$ $\mathrm{ha}^{-1}$ showed that this species is susceptible to $\mathrm{S}$ metolachlor, and high doses can cause damages in cells and tissues, reducing yield sorghum crops. However, sorghum plants endured applications this herbicide at doses lower than $960 \mathrm{~g} \mathrm{ha}^{-1}$ with intoxication symptoms of $12 \%$.

Sorghum, as well as sugar beet plants, can absorb a lesser amount of the herbicide due to more significant development of the hypocotyl tissues (ZEMOLIN et al., 2014) and S-metolachlor applications on sorghum plants in stage V2 can increase the tolerance of these species to the herbicide. Additionally, the sorghum plants can degrade the herbicide via oxidation or the glutathione-S-transferase (GST) (SLABA et al., 2015), reducing the toxicity of these plants at 28 DAA. Corn plants that absorbed $0.025 \mathrm{mg} \mathrm{kg}-1 \mathrm{~S}-$ metolachlor were able to degrade $80 \%$ of this herbicide in 10 days (CAO et al., 2008).

The increasing of S-metolachlor doses elevated weed control percentage at 7, 14 and 28 days after herbicide application (DAA). The 
application of atrazine alone at the rate of $2000 \mathrm{~g}$ ha ${ }^{1}$ promoted a weed control below $80 \%$ at $28 \mathrm{DAA}$
(Figure 3).

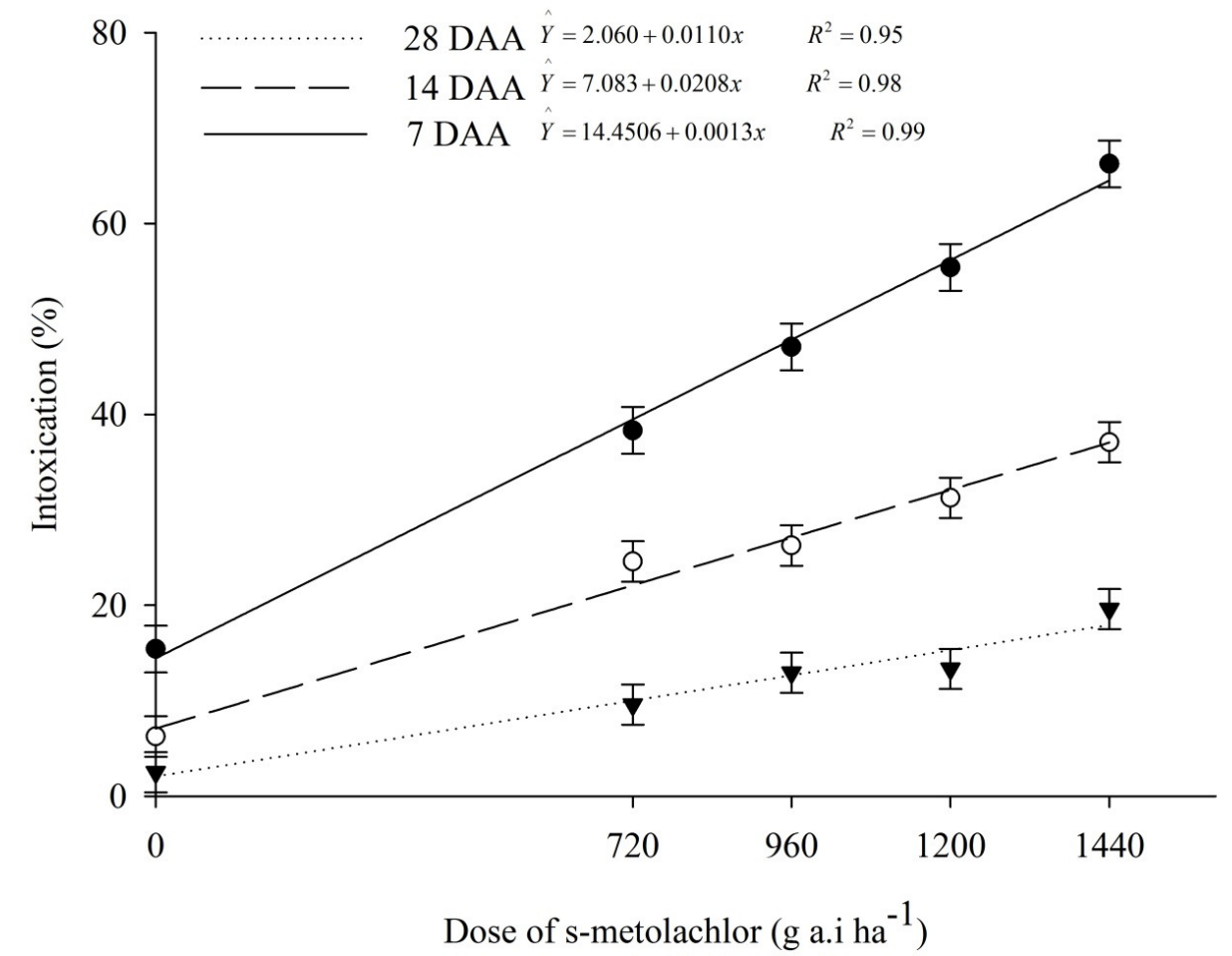

Figure 2. Intoxication (\%) of sweet sorghum plants (BRS 506) at 7, 14 and 28 days after the application of different rates of the atrazine + S-metolachlor mixture $\left(2000 \mathrm{~g} \mathrm{ha}^{-1}\right)$.

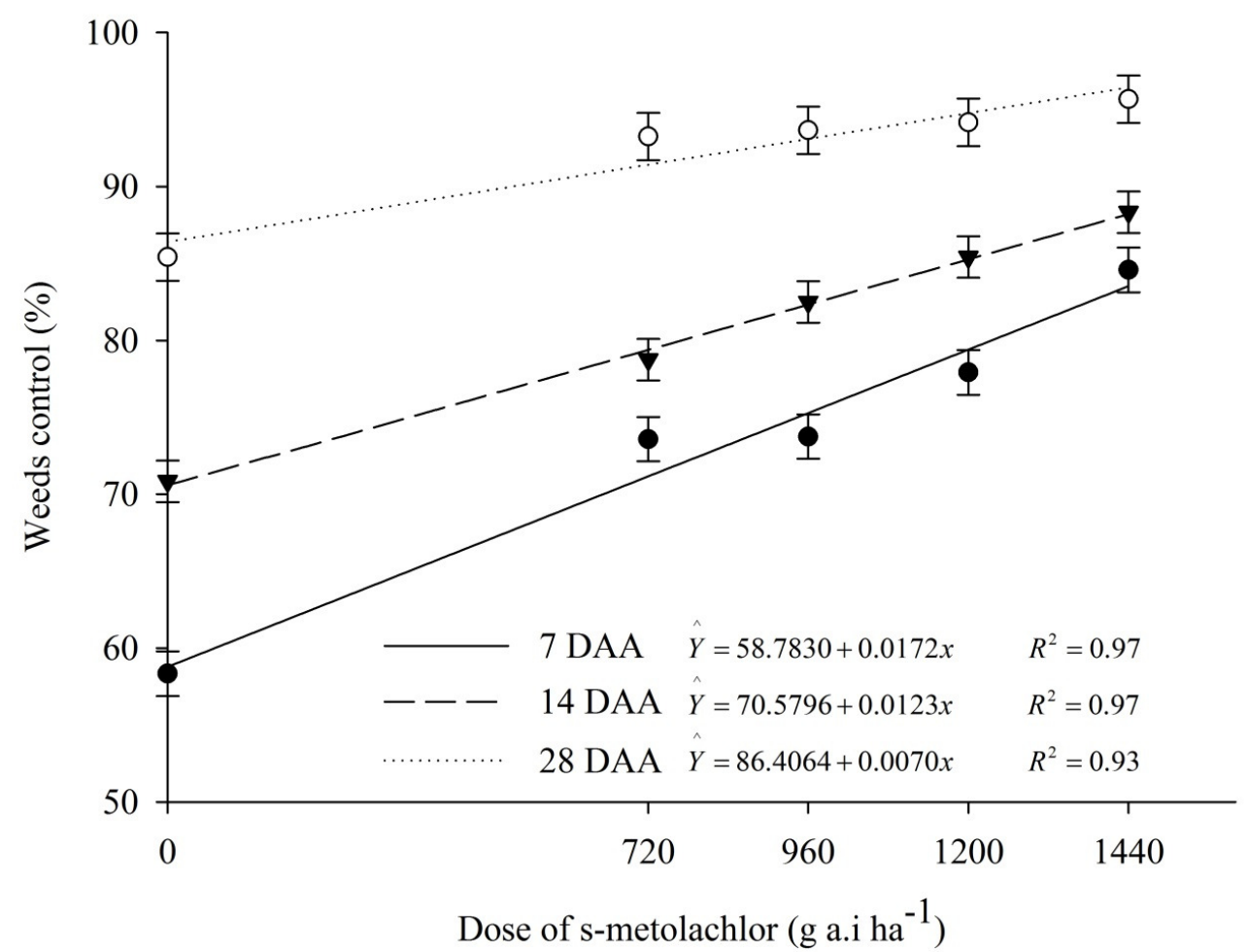

Figure 3. Percentage of weed control in sweet sorghum crops (BRS 506) at 7, 14 and 28 days. 
Atrazine was effective to control weeds species, such as $R$. raphanistrum, $C$. benghalensis, $S$. orientalis, $S$. trifoliata, $N$. physaloides, $E$. sonchifolia, and $C$. didymus. However, this herbicide did not efficient to control $D$. horizontalis, $E$. indica, and $U$. plantaginea, resulting in control percentage below $80 \%$ (BAHLER et al., 1984; RODRIGUES et al., 2014). The association with Smetolachlor provided the control of the species tolerant to atrazine, increasing weed control percentage at values above $90 \%$ even at lower doses. Atrazine application in areas with high weed diversity, principally where there are grass species, do not provide satisfactory control of weeds; thus, it is essential to use other herbicides with the different mode of action. Besides that, the herbicide association can avoid the appearance of weed resistant populations (RIAR et al., 2013; JIMÉNEZ et al., 2013).
Weed control and intoxication of sweet sorghum are increased by increasing the dose of Smetolachlor in the mixture with atrazine. The growth of sorghum is negatively affected by the application of the atrazine + S-metolachlor mixture, mainly at doses 1200 and $1440 \mathrm{~g} \mathrm{ha}^{-1}$ of Smetolachlor. The combination of atrazine and Smetolachlor adversely affects the ${ }^{\circ}$ Brix, and the magnitude of these effects depends on the dose of Smetolachlor. The $0.25 \mathrm{~m}$ spacing promotes a higher fresh matter and total soluble solids value in the sweet sorghum.

\section{ACKNOWLEDGMENTS}

The authors thank the Coordenação de Aperfeiçoamento de Pessoal do Ensino Superior CAPES grand number 001, Conselho Nacional de Desenvolvimento Científico e Tecnológico - CNPq and Fundação de Amparo a Pesquisa do Estado de Minas Gerais - FAPEMIG.

RESUMO: O objetivo desse trabalho foi avaliar os efeitos de arranjos de plantas e dos herbicidas atrazine e S-metolachlor sobre o crescimento e a produtividade do sorgo sacarino. O experimento foi realizado no delineamento em blocos casualizados, com quatro repetições. Os tratamentos foram dispostos em esquema de parcelas subdivididas. Nas parcelas avaliaram-se os espaçamentos entrelinhas $(0,25 \mathrm{~m}, 0,45 \mathrm{~m}$ e $0,45-0,45-$ $0,90 \mathrm{~m})$ e nas subparcelas os métodos de controle das plantas daninhas: atrazine $\left(2000 \mathrm{~g} \mathrm{ha}^{-1}\right)$, atrazine $+\mathrm{S}-$ metolachlor $\left(2000+720 \mathrm{~g} \mathrm{ha}^{-1}\right)$, atrazine + S-metolachlor $\left(2000+960 \mathrm{~g} \mathrm{ha}^{-1}\right)$, atrazine + S-metolachlor $(2000$ $\left.+1200 \mathrm{~g} \mathrm{ha}^{-1}\right)$, atrazine $+\mathrm{S}$-metolachlor $\left(2000+1440 \mathrm{~g} \mathrm{ha}^{-1}\right)$, capina manual e ausência de controle. Aos 7, 14 e 28 dias após a aplicação dos herbicidas foi avaliado a intoxicação das plantas de sorgo e o nível de controle de plantas daninhas na cultura. Aos 120 dias após a emergência da cultura avaliou-se altura de plantas, diâmetro de colmo, massa fresca total, massa de caldo e o teor de sólidos solúveis totais (Brix). Não houve interação entre os fatores espaçamentos e o método de controle para as variáveis massa fresca total (TMF), altura $(\mathrm{H})$, diâmetro do caule (D), peso do suco (JM) e Brix. O controle das plantas daninhas e a intoxicação visual do sorgo aumentaram linearmente com o incremento das doses do S-metolachlor. O crescimento da cultura e os teores de Brix foram reduzidos pela aplicação da associação entre atrazine + S-metolachlor. A escolha do espaçamento de entrelinha influenciou nos componentes de rendimento da cultura. Conclui-se que, o espaçamento de $0,25 \mathrm{~m}$ de entrelinhas proporcionou maior produtividade de matéria fresca e de Brix do caldo. A associação entre atrazine e S-metolachlor tem potencial para o uso no controle de plantas daninhas em sorgo sacarino, em doses abaixo de $960 \mathrm{~g} \mathrm{ha}^{-1}$ de S-metolachlor.

PALAVRAS-CHAVE: Sorghum bicolor. S-metolachlor. Atrazine. Biofuel.

\section{REFERENCES}

ALBUQUERQUE, C. J.; TARDIN, F.; PARRELLA R.; GUIMARÃES, A.; OLIVEIRA, R.; SILVA, K. Sorgo sacarino em diferentes arranjos de plantas e localidades de Minas Gerais. Revista Brasileira de Milho e Sorgo, 2012. 11, 69-85. https://doi.org/10.18512/1980-6477/rbms.v11n1p69-85

ALMODARES, A.; GOLI, M. Preliminary study on the effect of plant population density and sweet sorghum cultivars on bioethanol production. Biofuels, v. 4, n. 2, p. 163-167, 2013. https://doi.org/10.4155/bfs.13.2 
ARCHANGElO, E. R.; SILVA, A. A.; SILVA, J. B.; KARAM, D.; CARDOSO, A. A. Seletividade e eficácia de herbicidas aplicados em pós-emergência na cultura do sorgo forrageiro. Revista Brasileira de Milho e Sorgo, v. 1, n. 3, p. 107-115, 2002. https://doi.org/10.18512/1980-6477/rbms.v1n3p107-115

BAHLER, C. C.; VOGEL, K. P.; MOSER, L. E. Atrazine tolerance in warm-season grass seedlings. Agronomy journal, v. 76, n. 6, p. 891-895, 1984.

https://doi.org/10.2134/agronj1984.00021962007600060008x

BOLLMAN, J. D.; BOERBOOM, C. M.; BECKER, R. L.; FRITZ, V. A. Efficacy and tolerance to HPPDinhibiting herbicides in sweet corn. Weed Technology, v. 22, n. 4, p. 666-674, 2008.

https://doi.org/10.1614/wt-08-036.1

BRAZ, G. B. P.; MACHADO, F. G.; CARMO, E. L.; ROCHA, A. G. C.; SIMON, G. A.; FERREIRA, C. J. B. Desempenho agronômico e supressão de plantas daninhas no sorgo em semeadura adensada. Revista de Ciências Agroveterinárias, no prelo, 2019. https://doi.org/10.5965/223811711712018061

CAO, P.; WANG, X.; LIU, F.; ZHAO, E.; HAN, L. Dissipation and residue of S-metolachlor in maize and soil. Bulletin of environmental contamination and toxicology, v. 80, n. 5, p. 391-394, 2008.

https://doi.org/10.1007/s00128-008-9359-z

CLIMATE-DATA. Clima Viçosa. Disponível em: <https://pt.climate-data.org/america-do-sul/brasil/minasgerais/vicosa-25021/>. Acesso em: 18/01/2018.

EMBRAPA.; 1997. Empresa Brasileira de Pesquisa Agropecuária - EMBRAPA. Centro Nacional de Pesquisa de Solos. Manual de métodos de análise de solos. 2.ed. Rio de Janeiro. 212 p.

https://doi.org/10.17138/tgft(1)121-122

FERNANDES, P. G.; MAY, A.; COELHO, F. C.; ABREU, M. C.; BERTOLINO, K. M. Influence of spacing and plant population for sweet sorghum in different seeding seasons. Ciência Rural, v. 44, n. 6, p. 975-981, 2014.

GRONWALD, J. W.; FUERST, E. P.; EBERLEIN, C. V.; EGLI, M. A. Effect of herbicide antidotes on glutathione content and glutathione S-transferase activity of sorghum shoots. Pesticide Biochemistry and physiology, v. 29, n. 1, p. 66-76, 1987. https://doi.org/10.1016/0048-3575(87)90085-x

HAN, K. J.; PITMAN, W. D.; ALISON, M. W.; HARRELL, D. L.; VIATOR, H. P.; MCCORMICK, M. E.; DAY, D. F. Agronomic considerations for sweet sorghum biofuel production in the South-central USA.

BioEnergy Research, v. 5, n. 3, p. 748-758, 2012. https://doi.org/10.1007/s12155-012-9185-3

JIMÉNEZ, F.; FERNÁNDEZ, P.; ROJANO-DELGADO, A. M.; ALCÁNTARA, R.; DE PRADO, R. Resistance to imazamox in Clearfield soft wheat (Triticum aestivum L.). Crop Protection, v. 78, p. 15-19, 2015. https://doi.org/10.1016/j.cropro.2015.08.004

KATEROVA, Z. I.; MITEVA, L. P. E. Glutathione and herbicide resistance in plants. In: AscorbateGlutathione Pathway and Stress Tolerance in Plants. Springer Netherlands, 2010. p. 191-207. https://doi.org/10.1007/978-90-481-9404-9_6

LIU, H. J.; XIONG, M. Y.; TIAN, B. L. Comparative phytotoxicity of Rac-metolachlor and S-metolachlor on rice seedlings. Journal of Environmental Science and Health, Part B, v. 47, n. 5, p. 410-419, 2012. https://doi.org/10.1080/03601234.2012.657046

MAY, A. et al. Variedades de sorgo sacarino em diferentes espaçamentos e população de plantas. Revista Brasileira de Milho e Sorgo, v. 11, n. 3, p. 278-290, 2013. https://doi.org/10.18512/19806477/rbms.v11n3p278-290 
MAY, A.; SOUZA, V. F. D.; GRAVINA, G. D. A.; FERNANDES, P.G. Plant population and row spacing on biomass sorghum yield performance. Ciência Rural, v. 46, n. 3, p. 434-439, 2016. https://doi.org/10.1590/0103-8478cr20141133

MAY, A. et al. Manejo e tratos culturais. Embrapa Milho e Sorgo (ALICE), 2012. Available in: https://www.alice.cnptia.embrapa.br/bitstream/doc/940421/1/Doc139Manejotratos.pdf. Access in: February 2019.

MISHRA, J. S. Retrospect and prospects. Indian Journal of Weed Science, v. 47, n. 3, p. 246-253, 2015.

PEREIRA N. C. H. et al. Selectivity of bentazon and nicosulfuron in Crotalaria spectabilis intercropped with maize culture. Revista Caatinga, v. 32, n. 2, p. 381-389, 2019.

RATNAVATHI, C.; SURESH, K.; KUMAR, B.V.; PALLAVI, M.; KOMALA, V.; SEETHARAMA, N. Retrospect and prospects. Indian Journal of Weed Science, v. 47, n. 3, p. 246-253, 2015.

RIAR, D. S.; NORSWORTHY, J. K.; STECKEL, L. E.; STEPHENSON, D. O.; EUBANK, T. W.; SCOTT, R. C. Assessment of weed management practices and problem weeds in the midsouth United States-soybean: a consultant's perspective. Weed Technology, v. 27, n. 3, p. 612-622, 2013. https://doi.org/10.1614/wt-d-1200167.1

RODRIGUES, O. L.; GALVÃO, C.; CARLOS, J.; FERREIRA, E. A.; SILVA, D. V.; SANTOS, M. V.; FELIPE, R. S. Physiologic characteristics of corn and Urochloa brizantha (Hochst. ex A. Rich.) RD Webster in intercropping cultivation. Chilean journal of agricultural research, v. 74, n. 3, p. 257-262, 2014. https://doi.org/10.4067/s0718-58392014000300002

SBCPD - SOCIEDADE BRASILEIRA DA CIÊNCIA DAS PLANTAS DANINHAS. Procedimentos para instalação, avaliação e análise de experimentos com herbicidas. Londrina: SBCPD, 1995. 42 p.

SILVA, A.; ALBRECHT, A. J. P.; SILVA, G. S.; KASHIVAQUI, E. S. F.; ALBRECHT, L. P.; VICTORIA FILHO, R. Rates of Nicosulfuron Applied in Glyphosate-Tolerant and Sulfonylurea-Tolerant Soybean. Planta Daninha, v. 37, 2019.

SILVA, C.; SILVA, A. F.; VALE, W. G.; GALON, L.; PETTER, F. A.; MAY, A.; KARAM, D. Weed interference in the sweet sorghum crop. Bragantia, v. 73, n. 4, p. 438-445, 2014. https://doi.org/10.1590/16784499.0119

SŁABA, M.; RÓŻALSKA, S.; BERNAT, P.; SZEWCZYK, R.; PIĄTEK, M. A.; DŁUGOŃSKI, J. Efficient alachlor degradation by the filamentous fungus Paecilomyces marquandii with simultaneous oxidative stress reduction. Bioresource technology, v. 197, p. 404-409, 2015. https://doi.org/10.1016/j.biortech.2015.08.045

SMITH, C. W; FREDERIKSEN, R. A. (Ed.). Sorghum: Origin, history, technology, and production. John Wiley \& Sons, 2000.

THEODORO, J. G. C. et al. Herbicidas utilizados em milho no controle de soja voluntária. Revista Brasileira de Herbicidas, v. 17, n. 4, p. 616-1-8), 2018.

VERCAMPT, H.; KOLEVA, L.; VASSILEV, A.; VANGRONSVELD, J.; CUYPERS, A. Short-term phytotoxicity in Brassica napus (L.) in response to pre-emergently applied metazachlor: A microcosm study. Environmental Toxicology and Chemistry. Accepted Author Manuscript. doi:10.1002/etc.3538.

https://doi.org/10.1002/etc.3538 
WALSH, M. J.; STRATFORD, K.; STONE, K.; POWLES, S. B. Synergistic effects of atrazine and mesotrione on susceptible and resistant wild radish (Raphanus raphanistrum) populations and the potential for overcoming resistance to triazine herbicides. Weed Technology, v. 26, n. 2, p. 341-347, 2012. https://doi.org/10.1614/wt-d$11-00132.1$

WILLIAMS, M. M.; BOERBOOM, C. M.; RABAEY, T. L. Significance of atrazine in sweet corn weed management systems. Weed Technology, v. 24, n. 2, p. 139-142, 2010. https://doi.org/10.1614/wt-d-0900074.1

ZEMOLIN. C. R.; AVILA, L. A.; CASSOL, G. V.; MASSEY, J. H.; CAMARGO, E. R. Environmental fate of S-Metolachlor: a review. Planta daninha, v. 32, n. 3, p. 655-664, 2014. https://doi.org/10.1590/s010083582014000300022 